\title{
SUPERVISION OF HOTEL AND RESTAURANT TAX LEARNING TO IMPROVE REGIONAL ORIGINAL INCOME (PAD) SUMEDANG DISTRICT
}

\author{
Lalas Sulastri ${ }^{1}$, Prima Nugraha ${ }^{2}$ \\ ${ }^{1,2}$ Collage of Administrative Sciences Sebelas April Sumedang \\ ${ }^{1}$ lalassulastri04@gmail.com
}

\begin{abstract}
To manage hotel and restaurant taxes, it is absolutely necessary to have sufficient supervision and to supervise the implementation of hotel and restaurant taxes carried out by the Regional Revenue Service. The purpose of this study, namely to determine the implementation of supervision of hotel and restaurant tax collection, things that hinder and efforts that must be done to overcome obstacles to the implementation of supervision of hotel and restaurant tax collection in increasing the original revenue of Sumedang Regency. The method used in this research is qualitative method. With eight informants of research, namely the Head of the Regional Revenue Service, Head of Planning and Operations Control, Head of Control and Supervision Section, Executive Staff of Operational Control Planning, hotel and restaurant management. The results of the study show that controlling of hotel tax collection and restaurant tax to increase Sumedang Regency's original revenue has been effective but not yet maximally this can be seen from still encountered several obstacles, including the competency of tax collector officers, budget constraints and low awareness of taxpayers. However, it is expected that in the future there will be improvements in line with efforts to be carried out by the Regional Revenue Service of Sumedang Regency.
\end{abstract}

Keywords: supervision, hotel and restaurant tax, local revenue

\section{Introduction}

The birth of Law Number 23 Year 2014 concerning Regional Government, gives hope for regional governments to carry out regional development aspirations, needs and priorities. The birth of this Law was strengthened by Law Number 33 of 2004 concerning Financial Balance between Central and Regional Governments, in which regions were given the freedom to manage and regulate their finances without much interference from the central government.

In Law No. 33 of 2004, it is determined that the sources of revenue are from: (a) Regional Original Income (PAD); (b) Balancing Funds; (c) Other Income. Of the three components which are sources of regional income are PAD. Because it comes from the region itself and is collected by the region itself, so that the region's original income is a source of pure regional revenue and needs special attention from the regional government so that its revenues always increase.

According to Article 6 of Law Number 33 of 2004, it is explained that the intended PAD comes from: (a) Regional tax returns; (b) Results of regional retribution; (c) Results of management of other regional assets that are separated; (d) Other legitimate local revenues.

One of the results of regional taxes obtained by the regional government of Sumedang Regency, namely hotel and restaurant taxes. To manage hotel and restaurant taxes, it is absolutely necessary to have sufficient supervision and to supervise the implementation of hotel and restaurant taxes carried out by the Regional Revenue Service.

Hotel taxes are taxes on services provided by hotels, which include motels, inns, tourism huts, tourist houses, guest houses, lodging houses and the like, 
and boarding houses with more than ten rooms (10). Whereas restaurant tax is a tax on restaurant services. Meanwhile, this hotel and restaurant tax is one of the regional taxes whose collection system uses self-assessment, which means that the taxpayer calculates, pays and reports on the local taxes owed.

According to Mardiasmo (1994) the characteristics of tax collection with the self assessment method, namely:

a. Taxpayers are authorized to determine the amount of tax payable;

b. The taxpayer himself who calculates, deposits and reports on taxes owed;

c. The tax officer or tax officer does not interfere in the tax collection process but only supervises.

However, in reality the implementers of self assessment have not as a whole been able to comply with the regulations set by the local government. So that the Regional Revenue Service has difficulty in following up on existing problems. Problems that arise, among others, hotel and restaurant entrepreneurs do not want to show actual or dishonest turnover, besides paying taxes does not use tariffs, usually carried out by bargaining which is ultimately used with a price benchmark system. This causes tax revenue to be not optimal. Thus, the role of the tax authorities is needed in carrying out service, supervision, and guidance for taxpayers.

In addition, the tax object that has the potential to collect hotel and restaurant taxes in Sumedang Regency is small. There are 32 hotels and 89 restaurants recorded in 2018. However, when the hotel and restaurant tax collection is monitored effectively it does not rule out the possibility of an increase.

Another thing is the number of tax officers or tax authorities who monitor the field, so far there are only two (2) people from the ideal number that should be five (5) people. So that the supervision process can be said to be less than optimal.

Likewise, facilities and infrastructure supporting the implementation of supervision such as four-wheeled vehicles are still very lacking, which only has one (1) vehicle for operation, so that it can hamper monitoring.

Based on the background above, the problem identification was formulated as follows.

a. How is the supervision of collecting hotel and restaurant taxes in increasing the original revenue of Sumedang Regency?

b. What are the things that hinder the implementation of supervision of collecting hotel and restaurant taxes in increasing the original revenue of Sumedang Regency?

c. What efforts should be made to overcome barriers to the implementation of hotel and restaurant tax supervision in increasing the regional income of Sumedang Regency?

Meanwhile, the objectives expected from this research are to:

a. Knowing the implementation of supervision of collection of hotel and restaurant taxes in increasing the original income of the Sumedang Regency.

b. Knowing things that hinder the implementation of supervision of collecting hotel and restaurant taxes in increasing the original income of Sumedang Regency.

Knowing the efforts that must be made to overcome barriers to the implementation of hotel and restaurant tax supervision in increasing the original revenue of Sumedang Regency.

\section{Theoritical Framework}

When discussing hotel and restaurant taxes, it cannot be separated from the financial management of the area itself. Halim (2007), argues that: 
Regional Financial Management is a series of activities arranged systematically consisting of planning, implementation, administration, reporting, accountability and supervision of regional finance.

Thus it can be concluded that in discussing hotel and restaurant taxes this must include a series of planning, implementation, administration, reporting, accountability and supervision as an integral part of regional financial management.

\subsection{Controlling}

Siagian cited Silalahi (1989) defines supervision that:

The process of observation rather than the implementation of all organizational activities to ensure that all work being carried out goes according to a predetermined plan.

Meanwhile, Handayaningrat (1996) binds the definition of supervision as follows.

Supervision is a process where the leader wants to know whether the results of the work carried out by his subordinates are in accordance with the plans, orders, goals, or policies that have been determined. Obviously supervision must be guided by plans (planning) that have been decided, orders (orders) on the implementation of work (performance), goals and policies that have been predetermined.

A supervisory activity has a goal so that all forms of activities run and are carried out properly in accordance with a predetermined plan. According to Kusnadi et al (2002), the purpose of supervision in general includes: a. Measurement of compliance with policies, plans, procedures, regulations, and applicable laws.

b. Maintain the resources of the organization.

c. Achieving the goals and objectives set by the organization.

d. Trust in information and integrated information in the organization.

e. Ongoing performance and then compare actual performance with standards and increase the level of deviation and then find the right solution.

Meanwhile, the supervisory function itself is mentioned among others by Erni and Saefulah (2005), that the supervisory function consists of:

a. Evaluate the success and achievement of goals and targets in accordance with the indicators specified.

b. Take steps to clarify and correct any irregularities that might be found.

c. Perform various alternative solutions to various problems related to achieving business objectives.

To carry out supervision as intended, the right method is needed. Handayaningrat (1996) calls the method as follows.

a. Direct supervision; if the supervisory apparatus or the leadership of the organization conducts checks directly at the place of execution of work.

b. Indirect supervision; if the supervisory apparatus or the head of the organization checks the implementation of the work only through reports that enter him.

c. Formal supervision; supervision which is formally carried out by the supervisory apparatus unit acting on behalf of the head of the organization or the superior of the leadership of the organization.

d. Informal supervision; supervision not through formal channels or prescribed procedures. 
e. Administrative supervision; supervision covering the fields of finance, staffing and material.

f. Technical supervision; supervision of physical matters, for example: inspection of building construction, inspection of shipbuilding, inspection of rice planting in rice fields, and so on.

To prevent irregularities in the implementation of activities or work and at the same time make corrective actions in order to obtain an effective supervision system. The researcher stated the condition that the supervision be carried out effectively and efficiently as according to Handayaningrat (1996: 151) as follows.

a. Supervision must be related to one's plan and position.

b. Supervision must be connected with individual leaders and individuals.

c. Supervision must show deviations in important matters.

d. Supervision must be objective.

e. Supervision must be flexible.

f. Supervision must be economical.

g. Supervision must bring corrective action.

Based on the results of preliminary observations it can be seen that the factors that hinder the implementation of hotel and restaurant tax supervision, namely:

a. Staffing and employment; a job will be carried out properly if implemented with employees who have an educational background that is proportional to the work they do. But in the field there is a little more, a lot of which is not in accordance with the background, which has an impact on the work that is not effective and efficient.

b. Limited funding; the large amount of absorption of local revenue, especially from taxes, is not absorbed much, this is because the available resources are not in accordance with the number of tax objects that must be visited. c. Taxpayer awareness; The concept of picking up the ball is due to a lack of awareness of people or companies who are taxpayers.

The inhibiting factor for the implementation of the hotel and restaurant tax supervision above, of course, can be used as a strategy on how to or efforts to improve the supervision of hotel and restaurant tax itself, which includes personnel and employment, limited funding and awareness of taxpayers.

\subsection{Regional Taxes and Taxes}

Tax is payment of people's contributions to the government. Soemahamidjaja in Bohari (1985), argues that, "tax is a compulsory contribution in the form of money or goods collected by the authorities based on legal norms, in order to cover the cost of producing collective goods and services in achieving public welfare".

Meanwhile, according to Mardiasmo (2002) the so-called regional tax is, "Mandatory contributions made by individuals or entities to the regions without balanced direct compensation that can be forced based on applicable laws and regulations are used to finance the administration of regional government and regional development". Following are the arrangements for the types of regional taxes according to Law Number 28 of 2009 concerning Regional Taxes and Regional Retributions:

a. The type of provincial tax consists of:

1) Tax on motorized vehicles and vehicles in water;

2) Tax returns on the name of motorized vehicles and vehicles on water;

3) Motor vehicle fuel tax;

4) Tax on taking and utilizing underground water and surface water. 
b. The type of district regional tax consists of:

1) Hotel and restaurant tax;

2) Advertising tax;

3) Entertainment tax;

4) Parking tax;

5) Street lighting tax;

6) Tax collection and management of C minerals.

The tax collection system can be divided into three systems (Mardiasmo, 2011), namely as follows.

a. Official Assessment System; a collection system that authorizes the government (tax authorities) to determine the amount of tax owed by taxpayers.

b. Self Assessment System; a collection system that fully authorizes Taxpayers to calculate, calculate, pay, and self-report the amount of tax owed.

c. With Holding System; or a collection system that authorizes third parties (not the tax authorities and not the taxpayers concerned) to determine the amount of tax owed.

\subsection{Hotel Tax}

In accordance with Law Number 28 of 2009 Article 1 numbers 20 and 21, hotel tax is a tax on services provided by hotels. Whereas what is meant by hotels are facilities for lodging / resting services including other related services with a fee, which also includes motels, inns, tourism huts, tourist houses, guest houses, lodging houses and the like, and boarding houses with more than ten rooms (Siahaan, 2009).

\section{Tax Object Hotel}

Siahaan (2009) states that the object of hotel tax is a service provided by a hotel with payment, including supporting services as a complete hotel that provides convenience and comfort, including sports and entertainment facilities. Supporting services as a complete hotel are telephone, facsimile, telex, internet, photocopying, washing, ironing, transportation and other similar facilities provided or managed by the hotel.

\section{Hotel Subject and Taxpayer}

Siahaan (2009) states that being the subject of a hotel tax is an individual or entity that makes payments to individuals or entities that seek hotels. Simply put, the subject of tax is consumers who enjoy and pay for services provided by hoteliers. Whereas the hotel taxpayer is an individual or entity that seeks hotels, namely individuals or entities in any form in the company environment or work doing business in the field of lodging, including business people boarding houses, guesthouses, tourist huts, and meetinghouses that are responsible fully responsible for depositing the tax owed.

\section{Imposition Base and Hotel Tax Rate}

Siahaan (2009) states that the basis for imposing hotel taxes is the amount of payment or what should be paid to the hotel. If the payment is affected by a special relationship, the sale or replacement price is calculated on the basis of a fair market price at the time the hotel services are used. The hotel tax rate is set at a maximum of $10 \%$ (ten percent) and determined by the relevant regency / city regulations.

\section{Hotel Tax Reporting}

Siahaan (2009) states that hotel taxpayers must report to regents / mayors. Taxpayers who already have NPWPD at the beginning of the tax period must fill in the SPTPD. SPTPD is filled in clearly, completely and correctly and signed by the taxpayer or proxy and submitted to the mayor / regent or appointed official according to the specified period of time.

\subsection{Restaurant Tax}

In accordance with Law Number 28 Year 2009 Article 1 numbers 22 and 23, restaurant tax is a tax on services provided by restaurants. Whereas what is meant by restaurant is a facility for 
providing food and or drinks with a fee, which includes restaurants, cafeterias, canteens, stalls, bars and the like including catering / catering services (Siahaan, 2009).

\section{Tax Object Restaurant}

Siahaan (2009) states that the restaurant tax object is a service provided by a restaurant. Services provided by restaurants include the service of selling food and or drinks consumed by the buyer, both consumed at the service place and elsewhere. Included in the restaurant tax object are restaurants, cafes, bars, and others.

\section{Restaurant Subject and Taxpayer}

Siahaan (2009) states that restaurant taxes that are subject to tax are individuals or entities that buy food and / or drinks from restaurants. Simply put, the subject of tax is consumers who buy food and / or drinks from restaurants. Whereas those who are taxpayers are individuals or entities that run restaurants, namely individuals or bodies in any form that within the company or their work to do business in the restaurant sector.

Imposition Base and Hotel Tax Rate Siahaan (2009) states that the basis for restaurant taxation is the amount of payment received or that should be received by a restaurant. If payment is affected by a special relationship, the sale or replacement price is calculated on the basis of a fair market price at the time of purchase of food and / or drinks. Restaurant tax rates are set at a maximum of $10 \%$ (ten percent) and determined by the relevant regency / city regulations.

\section{Restaurant Tax Reporting}

Siahaan (2009) states that restaurant tax payers must report to regents / mayors, taxpayers who already have NPWPD at the beginning of the tax period must fill in the SPTPD. The SPTPD is filled in clearly, completely and correctly and signed by the taxpayer or proxy and delivered no later than fifteen days after the expiration of the tax period.

\section{Methodology}

The method used in this study is qualitative. This qualitative research method is called naturalistic research method because the research is carried out in natural conditions and the results of qualitative research emphasize more on meaning than generalization. Informants in this study, namely as many as ten (8) people were taken using purposive sampling technique, namely with the following details.

Tabel 1. Research Informant

\begin{tabular}{lll}
\hline No. & Informant & Total \\
\hline 1 & Head of Regional Revenue Service & 1 person \\
\hline 2 & Head of Planning and Operations Control & 1 person \\
\hline 3 & Head of Control and Supervision Section & 1 person \\
\hline 4 & Executive Operations Control Planning Staff & 1 person \\
\hline 5 & Hotel Manager & 2 persons \\
\hline 6 & Restaurant Manager & 2 persons \\
\hline Total & & $\mathbf{8}$ persons \\
\hline
\end{tabular}

To support the method used to obtain accurate information, the data collection techniques used are: a. Library study; data collection
techniques by studying
scientific books, applicable regulations, reports, archives and written documents relating to the problem under study that can support the smooth search of data.

b. Field studies; data collection techniques obtained directly in the 
field by means of observation, indepth interviews and documentation. Meanwhile, data processing in this study uses the Miles and Huberman models (in Sugiyono, 2014), namely:

a. Data reduction; reducing data means summarizing, choosing the main things, focusing on the important things, looking for themes and patterns and removing unnecessary ones.

b. Presentation of data; done in the form of brief descriptions, charts, relationships between categories, flowcharts and the like. Through the presentation of the data, the data is organized, arranged in a relationship pattern so that it will be more easily understood.

c. Conclusion withdrawal / verification; conclusions in the expected research are new findings that have never before existed. Findings can be in the form of descriptions or descriptions of objects that were previously dim or dark so that after being examined it becomes clear, it can be a causal or interactive relationship, hypothesis or theory.

\section{Result and Discussion}

To find out the implementation of supervision of hotel and restaurant tax collection, as well as things that hinder and efforts that must be made to overcome the obstacles to the implementation of hotel and restaurant tax supervision in increasing the original income of Sumedang Regency, the authors describe as follows.

\subsection{The supervision of collecting hotel and restaurant taxes in increasing the original revenue of the Sumedang Regency}

A supervisory activity has the aim that all forms of activities run and are carried out properly in accordance with a predetermined plan, or in other words can provide certainty whether the work has been carried out in accordance with the plans, instructions, provisions or rules and policies that have been set.

\section{Supervision Must be Connected With Someone's Plans and Position}

Implementation of supervision is a subsystem of the implementation of an activity, supervision is carried out as a form of control so that the goals, expectations and desires can be realized in accordance with the standards, vision and mission as well as the objectives of the organization.

Based on the results of the interview, it can be concluded that from the supervision indicators must be related to the plan and position of a person, in the implementation of supervision of hotel and restaurant tax collection in Sumedang Regency so far it has been in accordance with the predetermined plan. This is reinforced from the documentation obtained by researchers in the Sumedang District Revenue Service SKPD Work Plan 2017 and the Government Institution Performance Accountability Report (LAKIP) in 2016 stated that, in the implementation of supervision of hotel and restaurant tax collection in accordance with the supervisory organizational structure chart, namely carried out by the head of the field to be the supervisor of supervision under the auspices of the head of the department.

\section{Supervision must be connected with the individual leadership and personality}

Supervision is one of the processes in the implementation of management in an organization, which is also independent of government agencies because supervision has an important role in the progress of an oversight organization that will produce a quality output as well as supervision of the collection of hotel and restaurant taxes. One of the successes in the implementation of supervision is driven by the commitment of the leadership, this is because leaders who have strong authority in the 
implementation of supervision, the weaker commitment from the leadership in the implementation of supervision can lead to low performance output, and vice versa if the leader is committed strict supervision will produce good performance output.

Based on the results of interviews and observations from the supervision indicators, they must be linked to individual leaders and concluded that the leadership or Head of the Regional Revenue Service Office of Sumedang Regency is committed to carrying out supervision where the commitment is in line with the vision and mission of Sumedang District Revenue Service in transparent and accountable regional revenue management. The documentation results show that, in the 2013-2018 District Revenue Service Strategic Plan of the Sumedang Regency, the 2016 LAKIP and Sumedang District Regulation No. 9 of 2014 stated that the vision and mission of the Regional Revenue Service was, "Realizing Accountable and Transparent Regional Revenue Management in Order to Improve Community Welfare "and the Mission of the Regional Revenue Service of Sumedang Regency, namely:

a. Realizing accountability and transparency of regional revenue potential data;

b. Realizing Human Resources managing regional income;

c. Increase the effectiveness of extracting regional income sources.

\section{Supervision must show deviations from important things}

Improvement efforts are one of the best ways to improve a system so that the output or results of a job can be in line with expectations, with improvements, it will continue to improve the quality of the output or the results of a job. In its implementation, the leader is required and has an obligation to be able to give initiative and opinion in showing a deviant situation or error and provide a solution.
Based on the results of interviews and observations from supervisory indicators must show deviations in important matters, it can be concluded that the leadership, especially the head of the department, already knows the deviations that occur through work in the form of employment reports from employees.

\section{Supervision must be objective}

In the implementation of supervision, of course supervisors or supervisors must conduct an assessment, analyze the data in accordance with the reality in the field, so that the results of the supervision can be produced something that is quality and has improvement towards progress.

Based on the results of interviews and observations from the leadership indicators assessing and analyzing the work can the researcher be concluded that the leader always conducts analysis and gives an assessment of work and work results to subordinates in the form of delivering opinions to subordinates directly. Thus, in the implementation of supervision certainly must meet the procedures and stages in its implementation so that the implementation can be in accordance with the expectations and objectives of the implementation of the supervision. Standard procedure is an effort to standardize a system or procedure through details of a stage or activity, which has a specific purpose. The standard procedure in this case is related to the planning process of program activities.

\section{Supervision Must be Excellent}

The professionalism attitude of the supervisor must be truly implemented. Supervisors must exclude family values and kinship in their social environment. Implementing supervisors must be able to balance between personal interests and the interests of the organization or work.

Based on the results of interviews and observations, it can be concluded that the implementation of supervision and 
collection of taxes by officers is in line with expectations where officers are required to work professionally and exclude kinship from the supervisory officers to the officers and from the taxpayers. Basically, the implementation of supervision is certainly not going to be easy, in carrying out its duties sometimes taxpayers or targets always look for reasons to avoid payment, so one of the efforts that can be the strength of the supervisor is to show the legality of the show from the leadership.

\subsection{Things that hinder and efforts must be made to overcome barriers to the implementation of supervision of collection of hotel and restaurant taxes in increasing the original revenue of Sumedang Regency}

The implementation of supervisory activities certainly has a sequence and various stages in an effort to achieve a goal, which certainly is not all the implementation of supervision can be in line with expectations, things that interfere with achieving these objectives can be called obstacles that must be done so that the supervision can making the implementation of work more effective and easily achieved.

As for the question in analyzing the things that hinder the implementation of supervision of collection of hotel and restaurant taxes in increasing the original income of Sumedang Regency can be described as follows.

\section{Staffing and Employment}

Human Resources (HR) is the most important factor in supporting activities, with good quality human resources that will facilitate and facilitate the process of achieving supervision objectives.
Based on the results of interviews and observations, it can be seen that many supervisory officers are not yet competent in the field of information technology, auditing and computerization. This is reinforced, from the documentation obtained that in the Strategic Plan of the Regional Revenue Service of the Sumedang Regency in 2013-2018 on strategic issues based on tasks and functions, it was stated that weaknesses in the internal sector included, among others, a lack of competent human resources in the field. certain fields.

The efforts taken to overcome these obstacles, namely:

a. The Sumedang District Regional Revenue Service conducts training for hotel and restaurant tax collectors.

b. Strengthening the hotel and restaurant tax collection staff in training held by the District and Provincial Civil Service Offices (BKD).

c. Carry out visits and comparative studies with more advanced government institutions.

\section{Budget Limitations}

The budget is a sequence of funding needs in an activity, all needs related to the budget must be optimized so that there are no obstacles.

Based on the results of interviews and observations it can be concluded that, the constraints in meeting budgetary needs, namely the limited available budget so that the work of the Regional Revenue Service of Sumedang Regency has not been maximized, because it only utilizes the available budget by entering the 
program in accordance with the priority scale.

The efforts taken to overcome the limitations of this budget, namely by submitting a larger budget each year and turning the priority scale in accordance with the annual work plan. In measuring this priority scale, that is by first carried out through development planning deliberation activities (Musrenbang).

\section{Taxpayer Awareness}

Taxpayer awareness is a condition where the taxpayer knows, recognizes, respects and adheres to the applicable tax provisions and has the sincerity and desire to fulfill his tax obligations.

Based on the results of interviews and observations it can be concluded that, it turns out the obstacles faced, namely the attitude of taxpayers who do not care and assume that paying taxes is not important.

The efforts taken to increase awareness of these taxpayers, namely through approaches to taxpayers through socialization activities regarding the importance of paying and benefits from taxes.

\section{Conclusion}

Monitoring of hotel tax collection and restaurant tax to increase Sumedang Regency's original revenue has been effective but not yet maximally this can be seen from still encountered several obstacles, including the competency of tax collector officers, budget constraints and low awareness of taxpayers.

However, it is expected that in the future there will be improvements in line with efforts to be carried out by the Regional Revenue Service of Sumedang Regency.

\section{Reference}

Atmosudirdjo S. Prajudi, (1980), Administrasi dan Manajemen Umum, Jakarta, Ghalia.

Bohari, (2004), Pengantar Hukum Pajak, Jakarta, Rajawali.

Brotodihardjo R. Santoso, (2010), Pengantar Ilmu Hukum Pajak, Yogyakarta, Refika Aditama.

Diman Winarno, (2015), Penelitian dengan Judul Faktor-Faktor Yang Mempengaruhi Keberhasilan Pengawasan Kepala Dinas Pariwisata Pemuda dan Olahraga Kabupaten Sumedang. Sumedang STIA Sebelas April Sumedang.

Dwi Wahyuningsih (2010), Peran Pemimpin Dalam Melaksanakan Pengawasan Melekat Di Kantor Dinas Tenaga Kerja Provinsi Jawa Timur (Study Deskriptif Kualitatif), Surabaya, Universitas Pembangunan Nasional.

Dimock, (1978), Public Administrasion, Jakarta, Aksara Baru.

Halim, (2007), Akuntansi Keuangan Daerah, Jakarta, Salemba Empat.

Handayaningrat Soewarno, (1996), Pengantar Study Ilmu Administrasi dan Manajemen, Bandung, Sinar Biru Alagensindo.

Hasibuan S.P. Malayu, (2005), Manajemen Sumberdaya Manusia, Jakarta, PT Bumi Aksara.

Iskandar Jusman, (2014), Administrasi Negara dan Kebijakan Publik, Bandung, Puspaganda.

Kadarman, (2001), Pengantar Ilmu Manajemen, Jakarta, Gramedia Pustaka Utama.

LAN RI, (1996), Sistem Administrasi Negara Republik Indonesia, Jakarta, PT Toko Gunung Agung.

Mardiasmo, (1994), Perpajakan, Yogyakarta, Andi Publisher.

Moleong J. Lexy, MA, (2009), Metode Penelitian Kualitatif, Bandung, PT Remaja Rosda Karya. 
M.Manullang, (2007), Dasar-dasar Manajemen, Bandung, Mondar Maju.

Sarwoto, (1991), Dasar-Dasar Organisasi Manajemen, Jakarta, Ghalia.

Siagian P. Sondang, (2004), Filsafat Administrasi, Jakarta, Bumi Aksara.

Silalahi Ubert, (2002), Pemahaman

Praktis Azas-Azas Manajemen, Bandung, Mondar Maju.

Suganda Dann, (1996), Kapita Selekta Administrasi dan Pendapat Para Paka, Bandung, Arcan.

Sugiarto Endar, (1996), Pengantar Akomodasi dan Restoran, Jakarta, Gramedia Pustaka Utama.

Thoha Miftah, (2002), Ilmu Administrasi Kontenporer, Jakarta, RajaGrafindo.

Waldo Dwight, (1971), The Administrative State, Jakarta, Erlangga

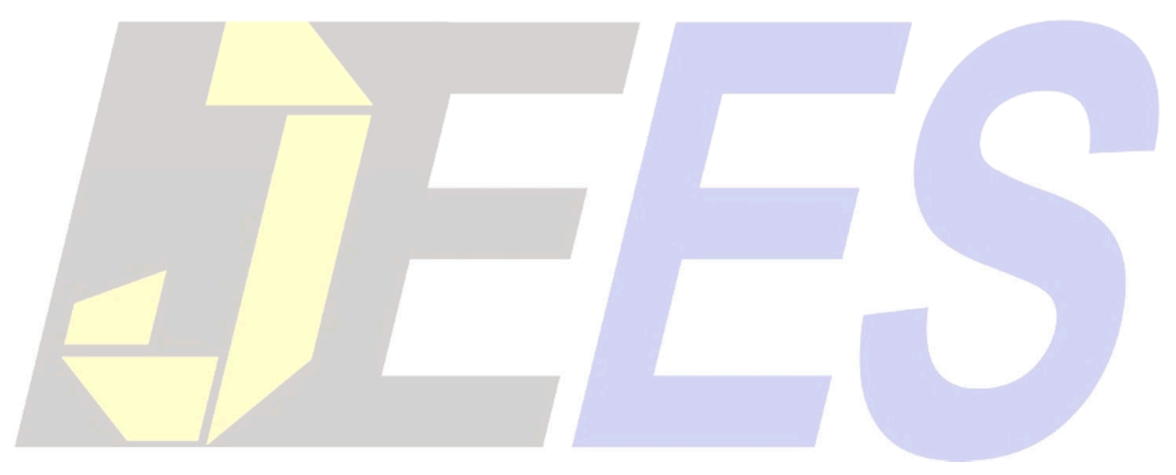

